\title{
SAFETY OF TRICLOPYR TRIETHYLAMINE TO NATIVE WETLAND SPECIES
}

\author{
P.D. CHAMPION ${ }^{1}$, T.K. JAMES ${ }^{2}$ and E.C. CARNEY ${ }^{2}$ \\ ${ }^{1}$ NIWA, PO Box 11-115, Hamilton, New Zealand \\ ${ }^{2}$ AgResearch, Ruakura Research Centre, PB 3123, Hamilton, New Zealand \\ Corresponding author: p.champion@niwa.co.nz
}

\begin{abstract}
Current management options for wetland weed control are limited. The triethylamine (TEA) salt formulation of the herbicide triclopyr effectively controls several broadleaf aquatic and wetland weed species and is relatively selective to many wetland species. To evaluate the tolerance of vegetation associated with weed species, a range of indigenous wetland species, including the widespread Dacrycarpus dacrydioides, Apodasmia similis, Carex virgata, Eleocharis acuta, Isachne globosa, Juncus pallidus, Triglochin striata, Phormium tenax and Mazus radicans, and the nationally endangered Carex cirrhosa, Amphibromus fluitans, Crassula helmsii and Selliera rotundifolia, were sourced from wild-collected or cultivated material and then grown on. Triclopyr TEA was applied to wetting at rates between $0.25 \%$ and $5 \%$. Dacrycarpus dacrydioides, I. globosa and A. fluitans appeared to have recovered fully from early damage from the $0.5 \%$ rate by the conclusion of the trial. Apodasmia similis, C. virgata, C. cirrhosa, E. acuta and $J$.pallidus were damaged but not completely killed at this rate, whereas the remaining five species were killed at all herbicide rates applied.

Keywords: aquatic herbicide, Garlon ${ }^{\circledR} 360$, herbicide tolerance, endangered plants.
\end{abstract}

\section{INTRODUCTION}

Methods of wetland weed control are, at present, limited to mechanical control and use of non-specific herbicides such as glyphosate and diquat. These often disturb existing vegetation and cause off-target damage that may lead to further weed invasion. The triethylamine (TEA) salt formulation of the herbicide triclopyr (3,5,6-trichloro2-pyridinyloxyacetic acid, Garlon ${ }^{\circledR} 360,404.5 \mathrm{~g}$ ai/litre) was registered in 2007 for aquatic plant control in New Zealand. It is reported to be relatively selective in its mode of action with little damage to grasses, sedges, rushes and aquatic monocotyledonous species (e.g.Anon. 2004). Champion et al. (2008) evaluated triclopyr TEA for the control of a range of wetland weeds, with good control of various broadleaf species including willows (Salix spp.), alder (Alnus glutinosa) and several herbaceous species. This paper reports the tolerance of a range of indigenous wetland plants that grow in association with those weed species.

\section{MATERIALS AND METHODS}

The indigenous species tested for tolerance to triclopyr TEA (3,5,6-trichloro-2pyridinyloxyacetic acid, Garlon ${ }^{\circledR} 360,404.5 \mathrm{~g}$ ai/litre) are listed in Table 1. 
TABLE 1: Native plants used in the trial, their conservation status (after de Lange et al. 2004) and associated weeds.

\begin{tabular}{|c|c|c|c|}
\hline Species & Common name & Endangered status & $\begin{array}{l}\text { Predominant associated } \\
\text { weed species }\end{array}$ \\
\hline $\begin{array}{l}\text { Dacrycarpus } \\
\text { dacrydioides }\end{array}$ & kahikatea & Not endangered & willows \\
\hline Apodasmia similis & oioi & Not endangered & $\begin{array}{l}\text { grey willow, purple } \\
\text { loosestrife }\end{array}$ \\
\hline Carex virgata & $\begin{array}{l}\text { pukio, swamp } \\
\text { sedge }\end{array}$ & Not endangered & all spp. \\
\hline Carex cirrhosa & & Gradual decline & willows \\
\hline Eleocharis acuta & spike sedge & Not endangered & all spp. \\
\hline Isachne globosa & swamp millet & Not endangered & willows \\
\hline Amphibromus fluitans & & $\begin{array}{l}\text { Nationally } \\
\text { endangered }\end{array}$ & All spp. \\
\hline Juncus pallidus & & Not endangered & alder, willows \\
\hline Triglochin striata & & Not endangered & purple loosestrife \\
\hline Phormium tenax & $\begin{array}{l}\text { harakeke, NZ } \\
\text { flax }\end{array}$ & Not endangered & $\begin{array}{l}\text { alder, willows, purple } \\
\text { loosestrife }\end{array}$ \\
\hline Mazus radicans & & Not endangered & $\begin{array}{l}\text { purple loosestrife (other } \\
\text { endangered Mazus spp.) }\end{array}$ \\
\hline Crassula helmsii & & Sparse & $\begin{array}{l}\text { water celery, monkey } \\
\text { musk }\end{array}$ \\
\hline Selliera rotundifolia & & Gradual decline & purple loosestrife \\
\hline
\end{tabular}

Plants of kahikatea, oioi, pukio, Juncus pallidus, harakeke and Mazus radicans were sourced from Annton Nursery, Cambridge. Spike sedge and swamp millet were collected from the vicinity of Hamilton City and the remaining species were grown at the NIWA plant collection, Ruakura, Hamilton. Plant material was grown in potting mix (Daltons Premium Mix) in the AgResearch glasshouse suite at Ruakura, for at least 2 months prior to herbicide application. At that stage the kahikatea, harakeke, oioi, spike sedge and swamp sedge and purple loosestrife were between 0.5 and $1 \mathrm{~m}$ tall. The remaining herbaceous species were treated once they formed dense mats over their pots. Triclopyr TEA was applied to plants outside the glasshouse on 13 October 2006, 2 November 2006, 21 December or 13 February 2007, depending on the growth stage and/or successful establishment of each species. Herbicide was applied to run off as $0.25,0.5,1.25,2.5$ or $5.0 \% \mathrm{v} / \mathrm{v}$ solutions, each with a non-ionic surfactant Citowett ${ }^{\circledR}$ at $0.025 \%$, using a knapsack sprayer. Five replicate pots were used for each treatment, with 5 untreated pots for a control. A second herbicide application at rates from 0.25 to $5 \% \mathrm{v} / \mathrm{v}$ was made to untreated Triglochin striata and Crassula helmsii plants on 21 December 2007. Plants were returned to the glasshouse after their foliage was dry.

Plants were monitored regularly after herbicide application. Monitoring involved visual assessment of the health of each plant compared to control plants, estimating percentage damage from 0 to $100 \%$. Except where there was little variation in the results, e.g. all $100 \%$, data were subjected to ANOVA to separate treatment means and the LSD was calculated. 


\section{RESULTS AND DISCUSSION}

Tables 2-8 show the rates of triclopyr TEA applied to each species tested and the resultant percentage damage. The broadleaf species $M$. radicans, $C$. helmsii and $S$. rotundifolia and the monocotyledons harakeke and T. striata were all killed (100\% damage) at all rates by the conclusion of the trial. Other monocotyledonous species in the Poaceae, Cyperaceae and Juncaceae and also the gymnosperm kahikatea were still alive, at least at the lowest rates. The two grasses I. globosa and A. fluitans completely recovered in all treatments apart from the 5\% rate, while kahikatea appeared to fully recover from the $0.5 \%$ rate.

TABLE 2: Percent damage to Carex virgata and Amphibromus fluitans after treatment with triclopyr (rate $(\% \mathrm{v} / \mathrm{v})$ in parentheses) on 13.10.06.

\begin{tabular}{lccccccccc}
\hline & \multicolumn{3}{c}{ Carex virgata } & & \multicolumn{4}{c}{ Amphibromus fluitans } \\
\cline { 2 - 4 } \cline { 7 - 9 } Treatment & 20.10 .06 & 1.12 .06 & 13.2 .07 & & 20.10 .06 & 13.2 .07 & 6.3 .07 & 10.4 .07 \\
\hline Untreated & 0 & 0 & 0 & & 0 & 0 & 0 & 0 \\
Triclopyr (0.5) & 0 & 23 & 41 & & 0 & 0 & 0 & 0 \\
Triclopyr (1.25) & 10 & 59 & 97 & & 29 & 10 & 5 & 0 \\
Triclopyr (2.5) & 38 & 100 & 100 & & 41 & 10 & 10 & 0 \\
Triclopyr (5) & 40 & 100 & 100 & & 57 & 54 & 28 & 20 \\
LSD $(\mathrm{P}<0.05)$ & 12.7 & 23.8 & 5.9 & & 11.0 & 6.2 & 5.5 & - \\
\hline
\end{tabular}

TABLE 3: Percent damage to Mazus radicans after treatment with triclopyr (rate (\% v/v) in parentheses) on 13.10.06.

\begin{tabular}{lcccc}
\hline Treatment & 16.10 .06 & 20.10 .06 & 1.12 .06 & 9.1 .07 \\
\hline Untreated & 0 & 0 & 0 & 0 \\
Triclopyr (0.5) & 20 & 15 & 92 & 99 \\
Triclopyr (1.25) & 26 & 21 & 100 & 100 \\
Triclopyr (2.5) & 36 & 30 & 100 & 100 \\
Triclopyr (5) & 48 & 52 & 100 & 100 \\
LSD $($ P $<0.05)$ & 9.4 & 10.6 & - & - \\
\hline
\end{tabular}

TABLE 4: Percent damage to Triglochin striatum after treatment with triclopyr (rate $(\% \mathrm{v} / \mathrm{v})$ in parentheses) on 13.10.06 or 21.12.06.

\begin{tabular}{lccccc}
\hline Treatment & 16.10 .06 & 20.10 .06 & 1.12 .06 & $9.1 .07^{1}$ & $13.2 .07^{1}$ \\
\hline Untreated & 0 & 0 & 0 & 0 & 0 \\
Triclopyr (0.25) & - & - & - & 82 & 100 \\
Triclopyr (0.5) & 0 & 5 & 100 & 90 & 100 \\
Triclopyr (1.25) & 15 & 7 & 100 & 93 & 100 \\
Triclopyr (2.5) & 20 & 16 & 100 & 94 & 100 \\
Triclopyr (5) & 40 & 50 & 100 & - & - \\
LSD $(P<0.05)$ & 3.2 & 6.5 & - & 4.6 & - \\
\hline
\end{tabular}

${ }^{1}$ Second experiment. 
TABLE 5: Percent damage to Crassula helmsii after treatment with triclopyr (rate $(\% \mathrm{v} / \mathrm{v})$ in parentheses) on 13.10.06 or 21.12.06.

\begin{tabular}{lccccc}
\hline Treatment & 16.10 .06 & 20.10 .06 & 1.12 .06 & $9.1 .07^{1}$ & $13.2 .07^{1}$ \\
\hline Untreated & 0 & 0 & 0 & 0 & 0 \\
Triclopyr (0.25) & - & - & - & 88 & 100 \\
Triclopyr (0.5) & 20 & 44 & 100 & 96 & 100 \\
Triclopyr (1.25) & 38 & 73 & 100 & 98 & 100 \\
Triclopyr (2.5) & 90 & 100 & 100 & 100 & 100 \\
Triclopyr (5) & 89 & 99 & 100 & - & - \\
LSD (P<0.05) & 13.4 & 14.7 & - & 4.9 & - \\
\hline
\end{tabular}

${ }^{1}$ Second experiment.

TABLE 6: Percent damage to Dacrycarpus dacrydioides and Phormium tenax after treatment with triclopyr (rate $(\% \mathrm{v} / \mathrm{v})$ in parentheses) on 2.11.06.

\begin{tabular}{lccccccccc}
\hline & \multicolumn{4}{c}{ Dacrycarpus dacrydoides } & & \multicolumn{3}{c}{ Phormium tenax } \\
\cline { 2 - 4 } Treatment & 6.11 .06 & 9.1 .07 & 6.3 .07 & 10.4 .07 & & 6.11 .06 & 1.12 .06 & 9.1 .07 \\
\hline Untreated & 0 & 0 & 0 & 0 & & 0 & 0 & 0 \\
Triclopyr (0.5) & 50 & 60 & 20 & 0 & & 30 & 74 & 100 \\
Triclopyr (1.25) & 58 & 74 & 30 & 24 & & 30 & 98 & 100 \\
Triclopyr (2.5) & 64 & 76 & 28 & 32 & & 40 & 97 & 100 \\
Triclopyr (5) & 82 & 90 & 100 & 100 & & 50 & 99 & 100 \\
LSD $(\mathrm{P}<0.05)$ & 13.8 & 5.9 & 6.8 & 5.4 & & 9.4 & 14.7 & - \\
\hline
\end{tabular}

TABLE 7: Percent damage to Selliera rotundifolia and Juncus pallidus after treatment with triclopyr (rate $(\% \mathrm{v} / \mathrm{v})$ in parentheses) on 21.12.06.

\begin{tabular}{lccccccc}
\hline & \multicolumn{2}{c}{ Selliera rotundifolia } & & \multicolumn{3}{c}{ Juncus pallidus } \\
\cline { 2 - 3 } \cline { 5 - 7 } Treatment & 9.1 .07 & 13.2 .07 & & 9.1 .07 & 6.3 .07 & 10.4 .07 \\
\hline Untreated & 0 & 0 & & 0 & 0 & 0 \\
Triclopyr (0.25) & 99 & 100 & & 32 & 66 & 52 \\
Triclopyr (0.5) & 100 & 100 & & 30 & 64 & 52 \\
Triclopyr (1.25) & 100 & 100 & & 50 & 75 & 78 \\
Triclopyr (2.5) & 100 & 100 & & 70 & 93 & 98 \\
LSD $(\mathrm{P}<0.05)$ & - & - & & 9.3 & 6.5 & 7.1 \\
\hline
\end{tabular}


TABLE 8: Percent damage to Eleocharis acuta and Isachne globosa after treatment with triclopyr (rate $(\% \mathrm{v} / \mathrm{v})$ in parentheses) on 21.12.06.

\begin{tabular}{lcccccccc}
\hline & \multicolumn{3}{c}{ Eleocharis acuta } & & \multicolumn{3}{c}{ Isachne globosa } \\
\cline { 2 - 4 } \cline { 7 - 9 } Treatment & 9.1 .07 & 6.3 .07 & 10.4 .07 & & 9.1 .07 & 13.2 .07 & 6.3 .07 \\
\hline Untreated & 0 & 0 & 0 & & 0 & 0 & 0 \\
Triclopyr (0.25) & 46 & 46 & 50 & & 28 & 0 & 0 \\
Triclopyr (0.5) & 44 & 78 & 76 & & 22 & 5 & 0 \\
Triclopyr (1.25) & 82 & 96 & 100 & & 36 & 5 & 0 \\
Triclopyr (2.5) & 98 & 100 & 100 & & 32 & 10 & 0 \\
LSD $(\mathrm{P}<0.05)$ & 7.8 & 7.4 & 5.7 & & 4.3 & - & - \\
\hline
\end{tabular}

TABLE 9: Percent damage to Apodasmia similis and Carex cirrhosa after treatment with triclopyr (rate $(\% \mathrm{v} / \mathrm{v})$ in parentheses) on 13.2.07.

\begin{tabular}{lcccccc}
\hline & \multicolumn{3}{c}{ Apodasmia similis } & & \multicolumn{2}{c}{ Carex cirrhosa } \\
\cline { 2 - 3 } \cline { 5 - 6 } Treatment & 6.3 .07 & 10.4 .07 & & 6.3 .07 & 10.4 .07 \\
\hline Untreated & 0 & 0 & & 0 & 0 \\
Triclopyr (0.25) & 6 & 8 & & 20 & 30 \\
Triclopyr (0.5) & 24 & 42 & & 20 & 30 \\
Triclopyr (1.25) & 50 & 68 & & 25 & 30 \\
Triclopyr (2.5) & 72 & 100 & & 30 & 52 \\
LSD $(\mathrm{P}<0.05)$ & 6.4 & 8.4 & & 5.6 & - \\
\hline
\end{tabular}

Members of the Cyperaceae, Juncaceae, Restionaceae and Poaceae are usually the dominant vegetation in herbaceous wetlands. These results show the relative tolerance of many of these indigenous monocotyledonous wetland species and also the swamp forest tree kahikatea (D. dacrydioides).

Hofstra et al. (2006) reported no damage to ditchbank grasses, the aquatic grass Glyceria declinata and pondweed Potamogeton cheesemanii, by triclopyr TEA application to control Myriophyllum aquaticum (parrot's feather). At Kaituna Wildlife Management Reserve, P. cheesemanii and the charophyte alga Nitella aff. cristata colonised the open areas left by M. aquaticum control using this herbicide (P.D. Champion, unpubl. data). Anon. (2004) list the following plants as tolerant to triclopyr TEA at the rates recommended for use in water: rushes (genera Juncus and Scirpus), Typha spp., Potamogeton spp., Ceratophyllum demersum, Elodea canadensis and Paspalum spp. Gabor et al. (1995) noted that grass density (stem number) was not affected by $3.8,7.6$ and $10.9 \mathrm{~kg}$ ai/ha rates, but sedge (Carex spp.) density initially declined at the highest treatment rate. However, sedge density recovered to pre-trial densities 1 year after herbicide application. These results were similar to the findings of the present trial. Assuming a water rate of 400 litres/ha, the herbicide application rates used in this trial varied between $8.1 \mathrm{~kg}$ ai $/ \mathrm{ha}(5 \% \mathrm{v} / \mathrm{v})$ and $0.4 \mathrm{~kg}$ ai $/ \mathrm{ha}(0.25 \% \mathrm{v} / \mathrm{v})$. Grasses were unaffected, but sedges and rushes were killed at the highest rate, with damage noted even at rates lower than those used by Gabor et al. (1995).

The butoxyethyl ester formulation of triclopyr is also widely used for managing problem terrestrial weeds, such as wandering Jew (Tradescantia fluminensis) and climbing asparagus (Asparagus scandens), in sensitive environments (Timmins \& Reid 2000; Standish 2002). When used under mature trees, including kahikatea, little 
damage was observed from this form of triclopyr, although some saplings were killed and seedling regrowth was impaired.

The concentrations applied to species in these pot trials are likely to be much higher than those received in a field situation, either because these plants would be present in the understory beneath a canopy of treated Alnus or Salix spp. and not receive the full dose of herbicide, or if the target weeds are spot sprayed - the spraying of nontarget plants can be avoided. Where susceptible species are present, the application of triclopyr TEA by more selective means (e.g. cut stump, drill and inject or wick wiper) or covering susceptible plants with impermeable material during herbicide application would prevent their damage.

Further evaluation of impacts on non-target species in the field is currently underway in the South Taupo Wetland, Cockayne Reserve in Christchurch and sites adjacent to the Waikato River. Preliminary evaluations showed limited off-target damage (P.D. Champion, unpubl. data).

Triclopyr TEA is therefore far more selective than existing herbicides and this selectivity would make it a beneficial tool for the management of dicotyledonous weeds in natural wetlands. Its use would also permit control of susceptible weeds near flowing waterways while maintaining a cover of grasses and other species beneficial to bank stability. Conversely, using triclopyr TEA to control willows in the presence of invasive grasses such as Glyceria maxima and Phalaris arundinacea, which are likely to be tolerant of triclopyr TEA, could facilitate the invasion of treated areas by these grasses.

\section{ACKNOWLEDGEMENTS}

The authors would like to thank the Department of Conservation for funding this project and also Ian Popay for assistance with trial design.

\section{REFERENCES}

Anon. 2004. Environmental impact statement (EIS) for permitted use of triclopyr. Washington State, Dept of Ecology Publication, Water Quality Program Publication No. 04-10-018. 115 pp.

Champion PD, James TK, Carney, E. 2008. Evaluation of triclopyr triethylamine for the control of wetland weeds. New Zealand Plant Protection 61: 374-377.

de Lange PJ, Norton, DA, Heenan PB, Courtney SP, Molloy BJP, Ogle CC, Rance BD, Johnson PN, Hitchmough R 2004. Threatened and uncommon plants of New Zealand. New Zealand Journal of Botany 42: 45-76.

Gabor TS, Haagsma HR, Murkin H.R, Armson E 1995. Effects of triclopyr amine on purple loosestrife and non-target plants in south-eastern Ontario, Canada. Journal of Aquatic Plant Management 33: 48-50.

Hofstra DE, Champion PD, Dugdale AM 2006. Herbicide trials for the control of parrot's feather. Journal of Aquatic Plant Management 44: 13-18.

Standish RJ 2002. Experimenting with methods to control Tradescantia fluminensis, an invasive weed of native forest remnants in New Zealand. New Zealand Journal of Ecology 26: 161-170.

Timmins SM, Reid W 2000. Climbing asparagus, Asparagus scandens Thunb.: a South African in your forest patch. Australian Ecology 25: 533-538. 